DOI: 10.20472/EFC.2021.015.005

\author{
BOŽENA KADEŘÁBKOVÁ \\ University of Economics, Prague, Czech Republic \\ EMILIE JAŠOVÁ \\ Faculty of Social Sciences, Charles University in Prague, Czech Republic

\section{HOW THE CZECH GOVERNMENT GOT THE PANDEMIC WRONG}

\begin{abstract}
:
The aim of the article is to prove by econometric analysis the suitability of NAIRU and NARRU concepts to assess the adequacy of measures against Covid 19 to address the epidemiological and economic situation in the Czech Republic. The analysis confirmed that in the Czech Republic the economy was reduced together with the escalation of the epidemic. The same development was found in the period March, April, October, November and December 2020 and February 2021. The government was therefore to take the path of greater prevention of the disease (eg timely adequate respirators, tests and vaccines). On the contrary, in January, February, May, June, July, August and September 2020 and January 2021, a lower value of NAIRU indicates an epidemiological-economic balance in the economy even with a higher unemployment rate. This is a consequence of the hasty tightening of anti-epidemiological restrictions.
\end{abstract}

\title{
Keywords:
}

Phillip's curve, NAIRU, NARRU, phases of the economic cycle, unemployment

JEL Classification: E24, E32, E37 


\section{Introduction}

The article presents the reasons for the long-term persistence of the Czech Republic as the most affected country in the world in terms of deaths per 100000 inhabitants. The article also provides evidence of the irrational behavior of the government that failed to learn from previous waves of the pandemic and repeated mistakes: failing to follow the pandemic plan, lack of protective equipment, low ability to make a model to predict the development of the epidemic, and neglect of expert advice.

The article uses an alternative concept of NAIRU to Tobin's concept of NAIRU (Tobin, 1997), i.e. the concept of Gadhia (2020). It replaces inflation with the reproduction number $R$ and assesses the possibility of avoiding a new wave of pandemics while maintaining economic activity. The new concept expresses the non-accelerating $R$ rate of unemployment (NARRU). It defines the capacity with which the economy can function safely in a pandemic. A comparison of the results from the two concepts shows when the epidemic-economic balance was reached at the cost of spreading the epidemic, and when, on the contrary, loosening of anti-epidemic measures could happen more quickly without accelerating the pandemic. In addition, it would help alleviate the recession.

First, we present the latest findings from international and domestic research from analyzes of the impact of Covid 19 on the NAIRU concept, the PC, and the unemployment gap. Then we present the anti-coronavirus measures of the Czech government and define the data incl. their sources and the individual steps of the analysis. The next part compares the development of NAIRU, NARRU, the unemployment gap, and the slope of the PC in the environment of the Covid 19 pandemic in the Czech Republic and we evaluate the results of NARRU. We compare the obtained conclusions with the results of other authors and present recommendations for the Czech government.

\section{Research results using the NAIRU concept, PC since 2013}

The long history of the relationship between inflation and unemployment confirms its applicability to the analysis of economic problems, despite strong criticism of this approach, especially in the last third of the 20th century. The applicability of the Phillips curve (PC) and NAIRU concepts is also supported by authors dealing with the effects of the global recession until 2015 (Gordon, 2013; Coibion and Gorodnichenko, 2015; Rusticelli, 2014; Andrle, Brůha and Solmaz, 2013; Baxa, Plašil and Vašíček, 2013). Further research from 2016 to 2020, examining the aftermath of a global recession, also confirms the functionality of both concepts (Blanchard, 2016; McLeay and Tenreyro, 2019; Zandweghe, 2019, Stock and Watson, 2017; D. Jula and N. Jula, 2017; Brubbak, Hagelund and Husabo, 2018; Alexius, Lundholm and Nielsen, 2020; Jašová and Kadeřábková, 2012).

Research since 2020 (i.e. the period of the first impact of Covid 19 on the concept of NAIRU, PC, and the unemployment gap) has provided evidence of PC recovery (Ebrahimy, Igan, and Peria, 2020, Brooks and Fortun, 2020, Gadhia, 2020). The research confirmed the deepening of uncertainties in the economy and thus the need for confidence-building measures in the ECB (European Parliament, 2020), the need for knowledge and risk assessment in the economy (Panetta, 2020) and highlighted the threat of disinflationary and inflationary pressures (Zandweghe, 2020).

This research was preceded by 240 years of examining the relationship between unemployment and inflation (Humphrey, 1985) starting with Hume (1752), Thornton (1802), Attwood (1816), Mill (1833) and Brown (1955), Phillips (1958). Until today, these concepts 
have had a number of successors: Samuelson and Solow (1960), Friedman (1968), Phelps (1967), Akerlof, Dickens and Perry (1996), Tobin (1997), Ball and Moffitt (2001), Fabiani and Mestre. (2001). The author of the NAIRU concept is considered Tobin (1997) and Gordon (1996), who considers NAIRU to be an unemployment rate that is consistent with a constant rate of inflation.

Gadhia (2020) proposes to base the strategy of opening and closing the economy using a PC, which instead of the inverse relationship between inflation and unemployment has an inverse relationship between the epidemic number $R$ and unemployment, e.g. non-accelerating $R$ rate of unemployment NARRU. An R number above 1 requires the economy to be closed, while a higher $\mathrm{R}$ requires a greater lockdown and thus has a greater negative impact on the economy and vice versa.

The government must monitor the balance in real-time, learn and adapt the process of gradual opening and closing of the economy according to the development of the reproductive number $\mathrm{R}$, which indicates the average number of other people directly infected by one infected patient (Ministry of Health CR, 2021). The government should differentiate measures according to both sectors and regions, as multiple equilibria occur in the economy, and keep number $\mathrm{R}$ below 1 . The economy at the time of Covid 19 is characterized by a combination of elements of the planned economy and market forces in order to achieve the best possible economic and epidemiological effects for society.

\section{Definition of data, their sources, and description of individual steps of analysis}

The initial indicator is the share of unemployed people (\%) by region and district from the Ministry of Labor and Social Affairs, hereinafter referred to as the MLSA (MLSA, 2021), as well as the average monthly eligibility for unemployment benefits (in CZK). The indicators consumer price index, import price index, industrial production, construction output (all month-on-month changes in \%), aggregate confidence indicator, business confidence indicator, and consumer confidence indicator (basic indices) were published by the Czech Statistical Office, CZSO (CZSO, 2021). Indicators of the CZK / EUR foreign exchange market rate (monthly averages), the price of Brent crude oil, indirect taxes (both indicated a monthon-month change in \%), and financial market inflation expectations (year-on-year change in \%) were taken over from the Czech National Bank and the CNB (CNB, 2021). Reproduction number $\boldsymbol{R}$ is published on the website Seznam Zprávy (Seznamzpravy.cz, 2021). Expectations about the development of the reproduction number $\boldsymbol{R}$ were published in the Records from the press conferences of the IHIS and the Ministry of Health - hereinafter referred to as the MOH CZ (MOH CZ, 2021).

The monitoring period from 1 January 2020 to the end of February 2021 was divided into five phases according to the intensity of anti-epidemiological restrictions. In the first phase, the Covid 19 infection was not proven in the Czech Republic. In the second phase, the economy and society were in a period of tough lockdown. In the third phase, the government relaxed anti-epidemiological restrictions. The fourth phase covers a period of a slight reduction in people's contacts. The fifth phase includes both a fundamental loosening of the economy and society, as well as a subsequent slight reduction in contacts, which culminated in severe anti-epidemiological restrictions (see Figure 1). 
Figure 1

Phases of anti-epidemiological measures according to the intensity of restriction

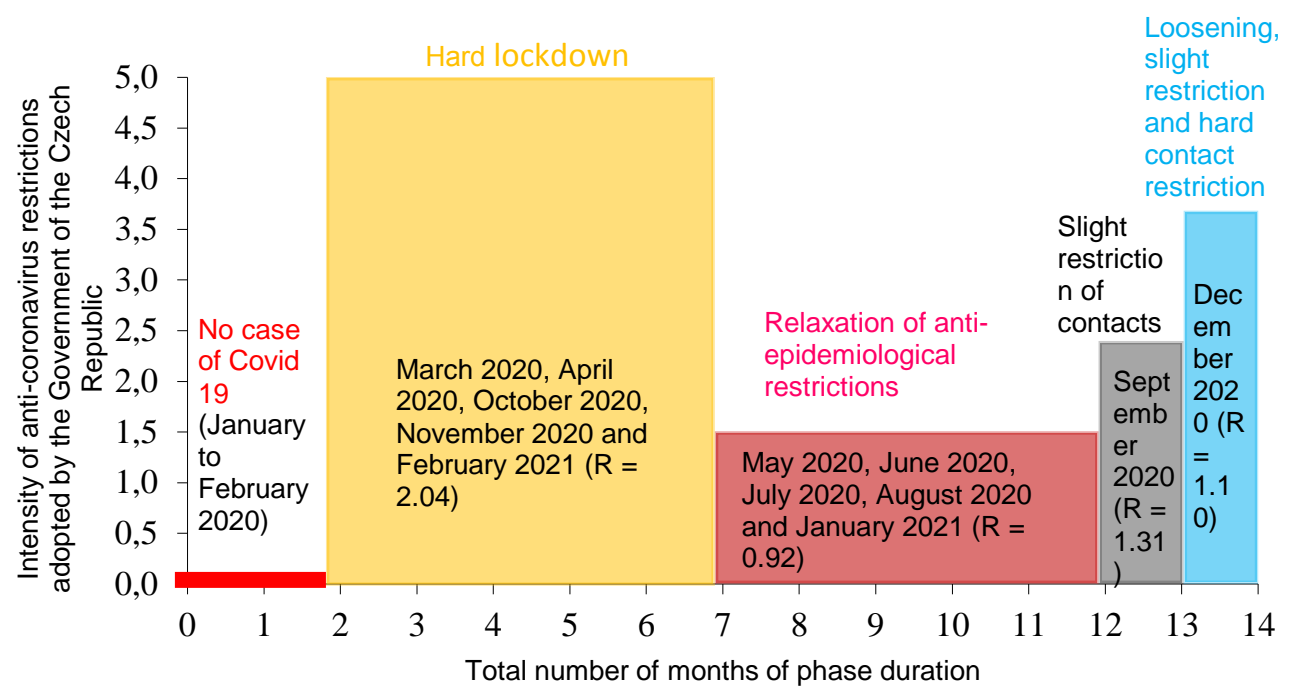

Source: Own representation based on information from ÚZIS, MOF and Bartoníček et al. (2021).

Y-axis data - own estimate of the value of the impact of anti-epidemic measures.

Multiple linear regression was applied to estimate NAIRU and NARRU. The inflation equation and the infection equation are estimated by the least-squares method. The calculation of NAIRU and NARRU is based on Sekhon's linear regression of the inflation equation (Sekhon, 1999). The gap in the share of unemployed people is created by subtracting NAIRU and NARRU from the actual share of unemployed people.

The Augmented Dickey-Fuller test was applied to test the stationarity of the used time series. Residue normality was tested by the Jarque Ber test, residual autocorrelation by the BresuchGodfrey test, and heteroskedasticity by the White test. The carrying capacity of multicollinearity is measured by the Variable Inflation Factor.

We are aware that the value of number $\mathrm{R}$ changed during the pandemic, however, a value of one as key to the epidemic condition was maintained. The unemployment rate was very inaccurate due to the support system. Without them, our conclusions about the relationship between $\mathrm{R}$ and the unemployment rate would be much more demonstrable.

\section{Mistakes of the Government of the Czech Republic in Covid 19 according to the NAIRU and NARRU concepts}

a) A comparison of the development of NAIRU and NARRU during anti-coronavirus measures by the Government of the Czech Republic shows, for example:

1) Because the NAIRU was higher than the NARRU throughout the period, the epidemiceconomic balance in the labor market was achieved at the cost of spreading the epidemic. The government should have been more consistent with epidemiological restrictions (e.g. longer, more complex, and stricter lockdowns) or should have placed more emphasis on disease prevention (e.g. have enough respirators, tests, and vaccines in time).

2) In the first period (January and February 2020) - the no-impact phase of Covid 19, the NAIRU was lower than NARRU (see Figure 2) and the government did not have to worry about 
inflationary pressures, as inflation expectations were fully under control. More relaxed monetary conditions would help regions with higher long-term unemployment rates, and the economy as a whole was booming.

3) The higher value of NAIRU in the second period (March, April, October, November 2020, and February 2021) - the phase of hard lockdown with restrictive measures against Covid 19 points out the presence of epidemic-economic balance in the labor market at the cost of accelerating the epidemic (Figure 2). The announced lockdown should have been longer and more comprehensive, more reflecting the views of epidemiologists and health professionals, more taking into account the situation in the regions.

4) The lower value of NAIRU than Narru in the third period (May, June, July, August 2020, and January 2021) - the phase of loosening of restrictive measures against Covid 19 admits, through epidemiological-economic balance, faster loosening using measures to alleviate the labor market recession (Figure 2). The government began to loosen the economy too late and slowly. An atypically negative NAIRU value indicates substitution failure, and NARRU fluctuated outside of the observed substitution.

5) The lower value of NAIRU in the fourth period (September 2020) - the phase of mild tightening of people's meetings with epidemiological measures against Covid 19 points to the achievement of epidemic-economic balance by hasty regulation of anti-epidemiological restrictions (Figure 2), which deepened the recession at a time of low epidemic in society. For example, the government did not have to limit mass events indoors. The atypical negative value of the NAIRU may be the first indication of the arrival of a structural shift in the labor market, but it did not occur due to massive support for companies and employment.

6) The higher value of NAIRU in the fifth period (December 2020) - the phase of major loosening of restrictions, gradual reduction of contacts, and tough measures against Covid 19 implies an epidemic-economic balance at the cost of accelerating the epidemic at a time when adequate tightening of restrictions would not escalate the labor market recession (Figure 2). The government should not have significantly relaxed measures before Christmas.

Figure 2

Development of NAIRU and NARRU in individual phases of pandemic restrictions for the whole Czech Republic

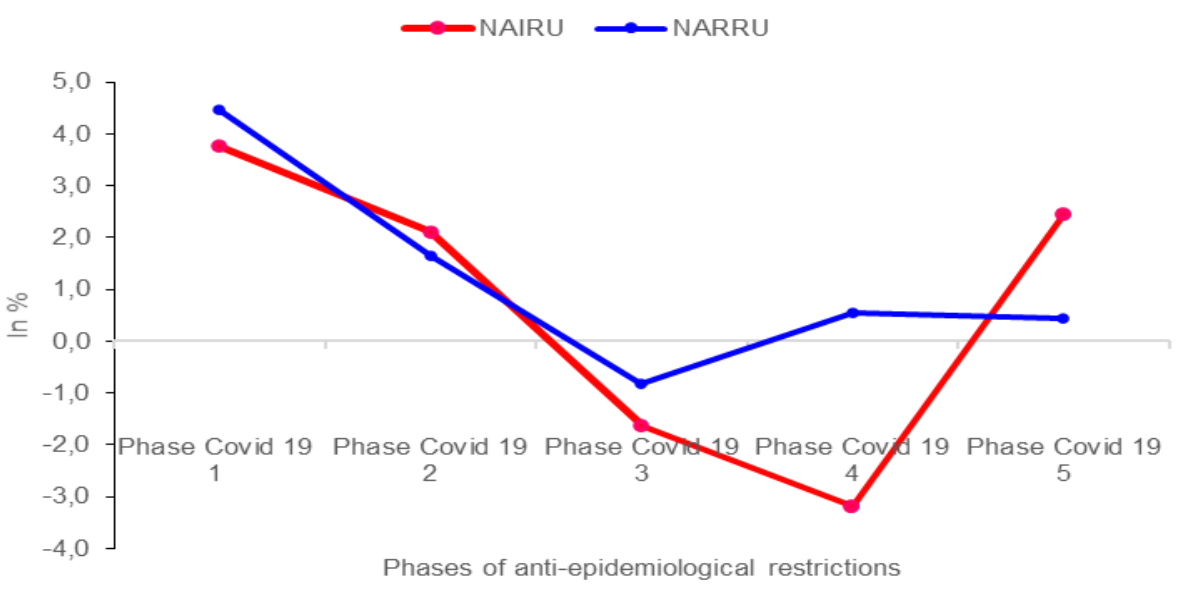

Source: Own calculation based on data from MPSV, ČSÚ, ČNB, ÚZIS and MZ.

b) A comparison of the development of the unemployment gap shows the following: 
1) The unemployment gap for the whole period from January 2020 to February 2021 was positive for both concepts, i.e. NAIRU and NARRU, and the labor market was in a recession phase. The lower value of the NAIRU concept implies less impact on the labor market by antiepidemic measures than what would be required by an epidemic burden in society.

2) The average value of the unemployment gap in the labor market in the first period for both concepts indicates a boom. Loose monetary policies imply a higher intensity of the economic boom for the NARRU concept (Figure 3), which improves the initial conditions for coping with the forthcoming epidemiological challenge of COVID 19 in the Czech Republic from the following month.

3) The average value of the unemployment gap in the labor market in the second period confirms the period of recession for both concepts. According to the NAIRU concept, the labor market was less affected from an economic point of view due to a non-complex and short lockdown (Figure 3).

4) The average positive unemployment gap in the labor market in the third period decreased compared to the previous period in the NARRU concept. A higher value for NAIRU indicates a faster and more rapid loosening of anti-pandemic measures and thus reduces the intensity of the recession without endangering the health of workers (see Figure 3). With the NAIRU concept, we can already talk about the beginning of structural shifts in the labor market. As for the NARRU concept, it is only a fluctuation due to rising oil prices.

5) The average positive unemployment gap in the labor market in the fourth period for the NAIRU concept increased with the decline in NARRU. The higher value of the NAIRU indicates the inadequacy of a pandemic restriction in the society which has deepened the recession in the labor market (see Figure 3). With the NAIRU concept, the correctness of the evaluation of the previous phase can be confirmed as a structural shift. For the NARRU concept, the correctness of the evaluation of the previous phase was confirmed as a one-time fluctuation.

6) The average positive value of the unemployment gap in the labor market in the fifth period decreased for the NAIRU concept and increased again for the NARRU. The lower value of the NAIRU shows how hesitation with a comprehensive lockdown reduced the impact on the labor market from an economic point of view and at the same time worsened the health aspect by accelerating the COVID 19 charge in society (see Figure 3).

Figure 3

Development of the unemployment gap according to the NAIRU and NARRU concepts in individual phases of pandemic restrictions for the whole Czech Republic

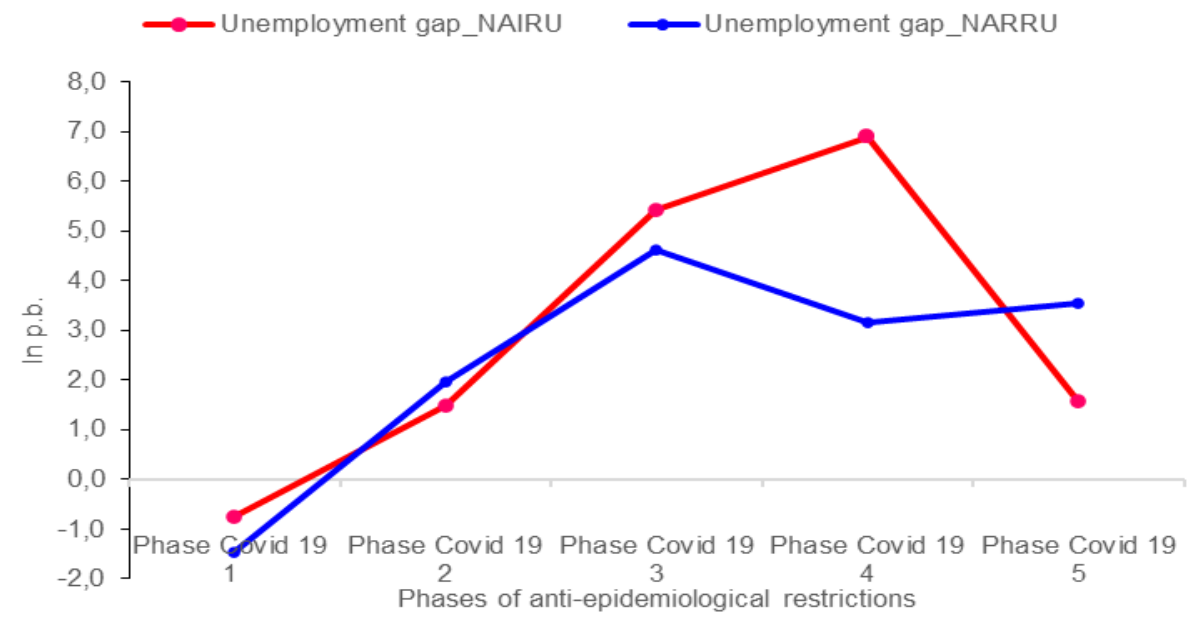


Source: Own calculation based on data from MPSV, ČSÚ, ČNB, ÚZIS and MZ.

c) PC slope analysis provides the following results:

1) The lower average value of the negative slope of the NAIRU concept in the whole monitored period confirms the suitability of the application of the NARRU concept for use in national economic practice. Overall, substitutability between inflation, resp. reproductive value of $R$, and unemployment is very weak.

2) The lower average value of the negative slope of PC in the first period at NAIRU confirms the advantages of the application of the alternative concept of NARRU by the government at the time of questioning the traditional concept of NAIRU due to flattening of PC (see Figure 4). The substitutability of the consumer price index is very weak and the PC is very flat, the substitutability of the reproduction number $R$ is medium and the PC has a medium slope.

3) The higher average value of the negative slope of the PC in the second period does not confirm with NAIRU the advantages of applying the alternative concept of NARRU (see Figure 4). The substitutability of the consumer price index and the reproduction number $R$ by the share of unemployed persons is very weak and the $P C$ very flat.

4) The average value of the PC slope in the third period was atypically positive for both concepts. At this stage, the theoretically defined trade-off for both concepts failed. For the NAIRU concept, this was due to the occasional changes between decades and semidecades, but also to the impact of the structural shift. In the case of the NARRU concept, it was only a temporary effect of sharp fluctuations in the development of oil prices.

5) The slope of the average PC in the fourth period for the NAIRU concept remained abnormally positive and for NARRU became negative again. For NAIRU, the structural shift violated the substitution between the consumer price index and the share of the unemployed persons. In the NARRU trade-off between the share of unemployed persons and the reproduction number was proved only in women. Once again, the advantage of applying an alternative NARRU concept for government decision-making is confirmed. (seeFigure 4).

6) The average value of the PC slope in the fifth period was again typically negative for both concepts and further accelerated. The lower slope of the NAIRU confirms the benefits of applying the alternative NARRU concept. (see Figure 4). The intensity of substitutability of the consumer price index, resp. reproduction number $\mathrm{R}$ by the share of unemployed persons is very weak and PCs are thus very flat.

Figure 4

Development of PC slope according to the NAIRU and NARRU concepts in individual phases of application of pandemic restrictions for the whole Czech Republic 


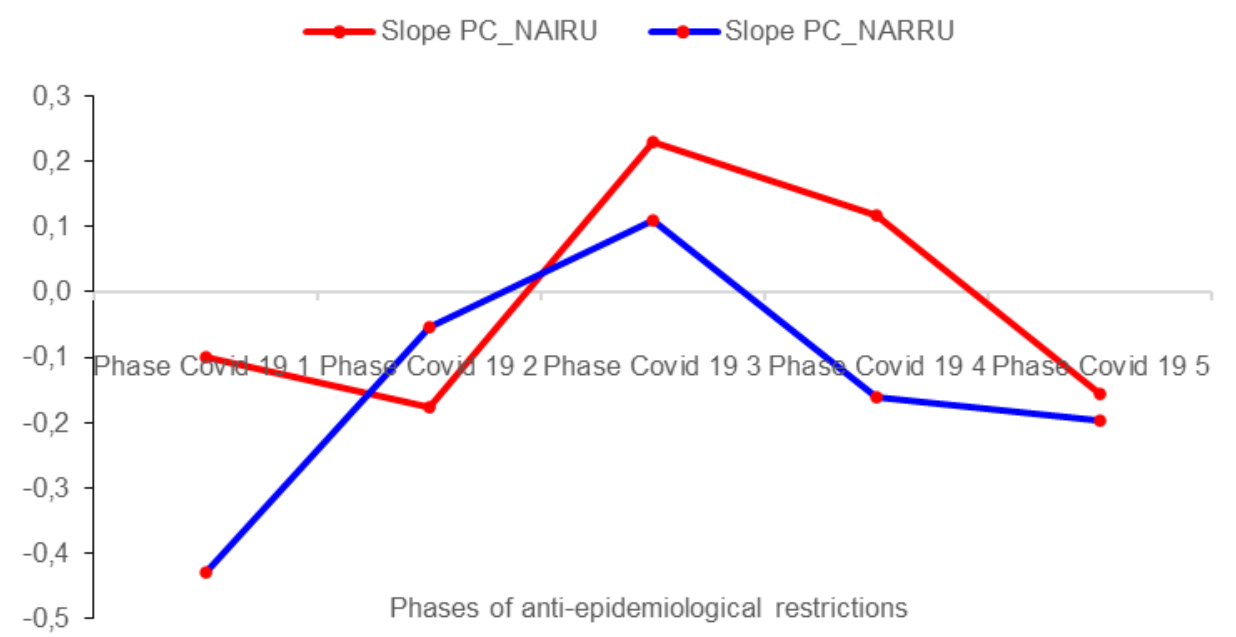

Source: Own calculation based on data from MPSV, ČSÚ, ČNB, ÚZIS and MZ.

\section{Conclusion}

The above analyzes show that a partial limitation of the economy was achieved in the Czech Republic at the cost of an escalation of the epidemic, as the average NAIRU values exceed the NARRU value in the entire monitored period. This conclusion is also confirmed by the Blatný study (2021), which states that restricting travel and overall mobility of people is an effective tool against the spread of a pandemic, and its effect increases with the length of the restriction. The government should therefore have placed more emphasis on previous infections (e.g. having enough respirators, tests, and vaccines in time), see Kulveit (2021), who states that inoculation of $1 \%$ of the population leads to a decrease in reproductive numbers $R$ by $1 \%$. According to both concepts, the unemployment gap for the whole period was positive, and thus the labor market was in a phase of recession. The average value of the PC slope according to both concepts for the whole Czech Republic has a classically negative slope, while it is lower for the NAIRU concept than for NARRU.

In the first period (January and February 2020) - a phase without a Covid 19 impact, the average values of NAIRU and NARRU were positive. The NAIRU was lower and thus the epidemiological-economic balance in the economy would have been achieved even with a higher unemployment rate. The average value of the unemployment gap in the labor market had a negative sign for both concepts, so the labor market was in a boom period. The average $P C$ slope value was typically negative for both concepts. The substitutability of the consumer price index is very weak and medium for the reproduction number $\mathrm{R}$.

In the second period (March, April, October, November 2020, and February 2021) - the phase of hard lockdown with restrictive measures against Covid 19, the average value of NAIRU and NARRU is positive. Because the value of the NAIRU was higher than the NARRU, the epidemic-economic balance in the labor market was reached at the cost of accelerating the epidemic. The average value of the unemployment gap in the labor market was positive, and for both concepts the labor market is in recession. The average value of the PC slope was negative for both concepts, the substitutability of the consumer price index and the reproduction number $\mathrm{R}$ by the share of unemployed persons is very weak.

In the third period (May, June, July, August 2020, and January 2021) - the phase of loosening restrictive measures against Covid 19, the average value of NAIRU and NARRU was negative, which indicates a period of instability. Given that the NAIRU is lower 
than the NARRU, the epidemic-economic balance in the labor market would probably also be achieved through a faster loosening of anti-epidemic measures. The average unemployment gap in the labor market was again positive. The average value of the PC slope was atypically positive for both concepts, and thus the theoretically defined trade-off failed.

In the fourth period (September 2020) - the phase of slight reduction of the meeting with epidemiological measures against Covid 19, the average value of NAIRU remained negative and NARRU was positive. The lower NAIRU corresponds to the hasty tightening of anti-epidemiological restrictions. The average positive unemployment gap in the labor market increased for the NAIRU concept as the NARRU decreased, which led to excess over the NARRU. The slope of the average $P \boldsymbol{C}$ for the NAIRU concept remained abnormally positive but returned to a negative value for NARRU, which confirms the advantage of applying an alternative NARRU concept for government decision-making.

In the fifth period (December 2020) - the phase of major loosening, gradual reduction of contacts, and tough measures against Covid 19, the average value of NAIRU and NARRU has a positive sign. The NAIRU is higher, which corresponds to the epidemic-economic balance in the labor market as the epidemic accelerates. The average positive value of the unemployment gap decreased for the NAIRU concept and increased again for NARRU, which led to a reduction in the economic impact on the labor market as the epidemic situation worsened. The average value of the PC slope was again typically negative for both concepts. The slope of NAIRU was lower than that of NARRU.

\section{References}

AKERLOF, G. A.; DICKENS, W. T.; PERRY, G. L. 1996. The Macroeconomics of Low Inflation. Brookings Papers on Economic Aktivity. Brookings Institution.

ALEXIUS, A.; LUNDHOLM, M.; NIELSEN, L. 2020. Is the Phillips curve dead? International evidence. Department of Economics, Stockholm University, pp. 26-27.

ANDRLE, M.; BRU゚HA, J.; SOLMAZ, S. 2013. Inflation and Output Comovement in the Euro Area: Love at Second Sight? Working paper Series 7. Česká národní banka. https://doi.org/10.5089/9781475538939.001

ATTWOOD, T. 1816. The Remedy; or, Thoughts on the Present Distresses. Second edition, with additions. London.

BALL, L.; MOFFITT, R. 2001. Productivity growth and the Phillips curve [Working paper series]. National Bureau of Economic Research.

BARTONíČEK, R.; VALÁŠEK, L.; CHRIPÁK, D.; ŠVEC, P.; KLÉZL, T. (2021). Anatomie selhání: Váhání a zmatek. Proč je Česko po roce pandemie $v$ nejtěžší krizi. Aktuálně.cz. https://zpravy.aktualne.cz/domaci/casova-osa-covid/r fd4c3f7e0ec511eb9d470cc47ab5f122/

BAXA, J.; PLAŠIL, M.; VAŠÍČEK, B. 2013. Inflation and the Steeplechase Between Economic Activity Variables. Working paper Series 15. Česká národní banka.

BLANCHARD, O. 2016. The United States Economy: Whereto from here? The Phillips Curve: Back to the '60s? American Economic Review: Papers \& Proceedings 2016, 106(5): 31-34 http://dx.doi.org/10.1257/aer.p20161003.

BLATNÝ, J. 2021. Co ukazují Blatného „tajná“ data? Když zavřít, tak nadlouho. https://www.google.com/search?q=Co+ukazuj\%C3\%AD+Blatn\%C3\%A9ho+\%E2\%80\%9Etajn\%C3\%A1\%E2 $\% 80 \% 9 \mathrm{C}+$ data\%3F+Kdy\%C5\%BE+zav\%C5\%99\%C3\%ADt\%2C+tak+nadlouho++Seznam+Zpr\%C3\%A1vy+(seznamzpravy.cz)\&oq=Co+ukazuj\%C3\%AD+Blatn\%C3\%A9ho+\%E2\%80\%9Etajn \%C3\%A1\%E2\%80\%9C+data\%3F+Kdy\%C5\%BE+zav\%C5\%99\%C3\%ADt\%2C+tak+nadlouho++Seznam+Zpr\%C3\%A1vy+(seznamzpravy.cz)\&aqs=edge..69i57.1800j0j4\&sourceid=chrome\&ie=UTF-8 
BROOKS. R.; FORTUN, J. 2020. Eurozone Output Gaps and the COVID-19 Shock. ZBW - Leibniz Information Centre for Economics, pp. 1-6. https://doi.org/10.1007/s10272-020-0918-9

BROWN, A. J. 1955. The Great Inflation, 1939-1951. London: Oxford University Press.

BRUBBAK, L.; HAGELUND, K.; HUSABO, E. 2018. The Phillips curve and beyond - Why has wage growth been so low? NORGES Bank, Staff Memo, No. 10/2018, ISSN 1504-2596 (online only), ISBN 978-82-8379-057-3 (online only), pp. 17.

COIBION, O.; GORODNICHENKO, Y. 2015. Is the Phillips Curve Alive and Well after All? Inflation Expectations and the Missing Disinflation. American Economic Journal: Macroeconomics 2015, 7(1), 197-232. https://doi.org/10.1257/mac.20130306

ČNB. (2021). Data použita $v$ analýze: Kurzy devizového trhu (https://www.cnb.cz/cs/financnitrhy/devizovy-trh/); Zpráva o inflaci - IV/2020 (https://www.cnb.cz/cs/menova-politika/zpravy-oinflaci/); Inflační očekávání finančního trhu (https://www.cnb.cz/cs/financni-trhy/inflacniocekavani-ft/)

Čsú. (2021). Data použita v analýze: Index spotřebitelských cen - inflace - únor 2021 (https://www.czso.cz/csu/czso/cri/indexy-spotrebitelskych-cen-inflace-unor-2021); Index cen vývozu a dovozu - leden 2021 (https://www.czso.cz/csu/czso/cri/indexy-cen-vyvozu-a-dovozu-leden2021); Konjunkturální průzkum - únor 2021 (https://www.czso.cz/csu/czso/cri/konjunkturalnipruzkum-unor-2021)

EBRAHIMY, E.; IGAN, D.; Peria, M.S. 2020. The Impact of COVID-19 on Inflation: Potential Drivers and Dynamics. IMF Research, pp. 1-14.

EVIEWS. 2013. EViews Version 7.2 Help Topics.

EVROPSKÝ PARLAMENT. 2020. Effects of Pandemic-Induced Uncertainty on Monetary Policy. Policy Department for Economic, Scientific and Quality of Life Policies Directorate-General for Internal Policies PE 658.203, IP/A/ECON/2020-58 Print ISBN 978-92-846-7462-6 | doi:10.2861/65871, pp. 57.

FABIANI, S.; MESTRE, R. 2001. A system approach for measuring the euro area NAIRU. ECB.

FRIEDMAN, M. 1968. The Role of Monetary policy. The American Economic Review.

GADHIA, J. LORD. 2020. Op-Ed: Britain needs an economic model to guide the lifting of the coronavirus lockdown. member of the U.K.'s House of Lords and a former senior managing director at the Blackstone Group, pp. 1-3. https://www.cnbc.com/2020/04/29/coronavirus-uk-britain-needs-aneconomic-model-for-lockdown-easing.html

GORDON, R. J. 2013. The Phillips Curve is alive and well: Inflation and the NAIRU During the Slow Recovery. National Bureau of Economic Research. Cambridge. Working Paper 19390.

GORDON, R. J. 1996. Problems in the Measurement and Performance of Service-sector Productivity in the United States. National Bureau of Economic Research, March 1996.

HUME, D. 1752. Of Money. Political Discourses by David Hume. Presented by the Worshipful Company of Goldsmiths, 1903.

HUMPHREY, T. M. September/October 1985. The early History of the PHILLIPS CURVE. Economic Review. Federal Reserve Bank of Richmond.

JAŠOVÁ, E.; KADEŘÁBKOVÁ, B. 2012. Comparing NAIRU and Economic Cycle from the Perspective of Labour Market in the Countries of the Visegrad Group. Economic Studies journal, Bulgarian Academy of Scienties,p. 3-23, Sofia, Issue 4, volume XXI, ISSN 0205-3292. Bulharsko.

JULA, D.; JULA, N. 2017. The Phillips Curve for the Romanian Economy, 1992-2017. Computational Methods in Social Sciences, pp. 45-46. 
KULVEIT, J. 2021. „Brzy skončí poslední lockdown.“ Kulveit vidí jediné riziko. https://www.google.com/search?q=\%E2\%80\%9EBrzy+skon\%C4\%8D\%C3\%AD+posledn\%C3\% AD+lockdown.\%E2\%80\%9C+Kulveit+vid\%C3\%AD+jedin\%C3\%A9+riziko++Seznam+Zpr\%C3\%A1vy+(seznamzpravy.cz)\&oq=\%E2\%80\%9EBrzy+skon\%C4\%8D\%C3\%A D+posledn\%C3\%AD+lockdown.\%E2\%80\%9C+Kulveit+vid\%C3\%AD+jedin\%C3\%A9+riziko++Seznam+Zpr\%C3\%A1vy+(seznamzpravy.cz)\&aqs=edge..69i57.1671j0j1\&sourceid=chrome\&i $\mathrm{e}=\mathrm{UTF}-8$

MCLEAY, M.; TENREYRO, S. 2019. Optimal Inflation and the Identification of the Phillips Curve. Bank of England, pp. 38-39. https://doi.org/10.1086/707181

MILL, S. J. 1833. „The Currency Juggle“. Taitś Edinburg Magazine (1833). Reprinted in Vol. I of his Dissertations and Discussions. Boston: 1865.

MPSV. (2021). Data použita $v$ analýze: Podíl nezaměstnaných osob $v \quad \%$ (https://www.mpsv.cz/web/cz/mesicni); Průměrný měsíční nárok na podporu v nezaměstnanosti v Kč (https://www.mpsv.cz/web/cz/struktura-uchazecu)

MZ. 2021. Data použita v analýze: Očekávání ÚZIS a MZ reprodukčního čísla $R$ - Záznam z tiskové konference (https://onemocneni-aktualne.mzcr.cz/covid-19/zpravy-a-prezentace)

PANETTA, F. 2020. The price of uncertainty and uncertainty about prices: monetary policy in the postCOVID-19 economy. Keynote speech by Fabio Panetta at a Capital Markets webinar organised by the European Investment Bank and the European Stability Mechanism. Frankfurt am Main, 1 July 2020, pp. 1-8.

PHELPS, E. S. 1967. Phillips Curves, Expectations of Inflation and Optimal Unemployment Over Time. Economica.

PHILLIPS, S, A. W. (1958). The relationship between unemployment and the rate of change of money wages in the United Kingdom 1861-1957. Economica. https://doi.org/10.2307/2550759

RUSTICELLI, E. 2014. Rescuing the Phillips curve Making use of long-term unemployment in the measurement of the NAIRU. OECD Journal: Economic Studies. Vol. 2014/1. https://doi.org/10.1787/eco_studies-2014-5jxrcm2cdff6

SAMUELSON, P. A.; SOLOW, R. M. May 1960. Analytical aspects of Anti-inflation Policy. American Economic Association.

SEKHON, J. S. 1999. Estimation of the Natural Rate of Unemployment: 1955:01-1997:12. Harvard University, Berkeley.

SEZNAMZPRAVY.CZ. 2021. Data použita v analýze. https://www.seznamzpravy.cz/clanek/ pdrobnamapa-kde-je-v-ceske-republice-koronavirus-93746

STOCK, H. J.; WATSON, W. M. 2017. Twenty Years of Time Series Econometrics in Ten Pictures. The Journal of Economic Perspectives, Vol. 31, No. 2 (Spring 2017), pp. 59-86. https://www.jstor.org/stable/44234999.

THORNTON, H. 1802. An Enquiry into the Nature and Effects of the Paper Credit of Great Britain. Edited with an introduction by F. A. von Hayek. New York Rinehart and Company, Inc. 1939.

TOBIN, J. 1997. Supply Constraints on Employment and Output: NAIRU versus Natural Rate. Cowles Foundation Paper 1150. Yale University, New Haven.

ZANDWEGHE, V.W. 2019. The Phillips Curve and the Missing Disinflation from the Great Recession. Economic Review, Second Quarter 2019. Reserve Bank of Kansas City. pp. 18-19. 